\title{
A NUMERICAL STUDY TO IMPROVE THE POSITION AND ANGLE OF THE PRODUCER GAS INJECTOR INSIDE THE INTAKE MANIFOLD TO MINIMIZE EMISSIONS AND EFFICIENCY ENHANCEMENT OF A BI ENGINE
}

\author{
Hussein A. Mahmood $\bowtie$ \\ Department of Reconstruction and Projects ${ }^{1}$ \\ husseinadel@uobaghdad.edu.iq \\ Ali O. Al-Sulttani \\ Department of Water Resources Engineering \\ College of Engineering ${ }^{l}$ \\ Osam H. Attia \\ Department of Reconstruction and Projects ${ }^{I}$ \\ Nor Mariah. Adam \\ Department of Science and Technology \\ Universiti Putra Malaysia Bintulu Sarawak Campus \\ Nyabau Road, Bintulu, Sarawak, Malaysia, 97008 \\ ${ }^{1}$ University of Baghdad \\ Karrada, Al-Jadriya - Baghdad, Iraq
}

$\triangle$ Corresponding author

\begin{abstract}
To develop a petrol engine so that it works under the bi-engine pattern (producer gas-petrol) without any additional engine modifications, a single-point injection method inside the intake manifold is a simple and inexpensive method. Still, it leads to poor mixing performance between the air and producer gas. This deficiency can cause unsatisfactory engine performance and high exhaust emissions. In order to improve the mixing inside the intake manifold, nine separate cases were modelled to evaluate the impact of the position and angle orientation inside the intake manifold on the uniformity and spread of the mixture under AFR $=2.07$. A petrol engine $(1.6 \mathrm{~L})$, the maximum engine speed $(8000 \mathrm{rpm})$, and bi-engine mode (petrol-producer gas engine). The employ of the numerical simulation software (ANSYS workbench 19), the propagation, flow characteristics, and uniformity of the blend within the nine different cases were evaluated. According to the outcomes of the numerical simulation, it was found that creating vortices and turbulent flow for the producer gas and air inside the intake manifold is the perfect method to obtain a uniformity mixture of air and producer gas inside the intake manifold. In addition, extending the blending duration allows air and producer gas fuel to be mixed efficiently. Furthermore, the greatest uniformity and the maximum spread rate at the outlet of manifold are obtained in cases 1, 4, and 7, when the producer gas injector location is constant (P1, P2 or P3). In addition, the weakest spread of producer gas at the outlet of the manifold is observed in case 9 in comparison with the other cases. Moreover, it is observed that case (1) generated the maximum uniformity index (UI) level.
\end{abstract}

Keywords: mixture homogeneity, gas injector orientation, producer gas, computational fluid dynamics, environment.

DOI: $10.21303 / 2461-4262.2021 .002045$

\section{Introduction}

The energy crisis deeply impacted negatively on the environment by increasing its contamination [1]. Many methods are used to reduce this effect by figuring out a new power source such as renewable energy $[2,3]$. Significant contributions of renewable energy are appeared by the reduction of environment contamination depends on many developed techniques such as electric cars, fuel cells, biomass, hydrogen, LPG, methane, and solar-powered vehicles, these techniques have been used to reduce the emission levels from the transportation sector [2, 4]. Of all the renewable 
resources of power for rural regions, the producer gas (PG) from biomass seems to have the highest opportunity $[5,6]$. Farming countries have a vast amount of biomass sources. It is reported that between 40 and 60 percent of farming crop residues are either wasted or put to inefficient usage. The producer gas was created by biomass gasification from solid carbonaceous fuels such as coal, wood, charcoal, agricultural and forest wastes, and also animal residues [7, 8]. With combustible components; being methane $\left(\mathrm{CH}_{4}\right)$, carbon monoxide $(\mathrm{CO})$, carbon dioxide $\left(\mathrm{CO}_{2}\right)$, nitrogen $\left(\mathrm{N}_{2}\right)$, hydrogen $\left(\mathrm{H}_{2}\right)$, and other trace hydrocarbons at low temperatures between $700{ }^{\circ} \mathrm{C}$ to $1000{ }^{\circ} \mathrm{C}$, where the producer gas be used directly as a fuel gas $[9,10]$.

Using producer gas in bi-engine petrol mode not only permits the cultivation of alternative fuels for cleaner combustion but also enhances the economy of the fuel. A single-point injection is a simpler and cheaper method for changing a petrol engine so that it works in bi-engine phase without any additional alterations to the engine [4, 11-13]. But using a single-point injection leads to poor mixing performance between the air and producer gas. This deficiency can cause unsatisfactory engine performance and high exhaust emissions. The producer gas is stimulated in the bi-engine together with the intake air and compressed as in a traditional petrol engine. The mixture of air and producer gas is ignited by the spark plug. Moreover, the most crucial aspects impacting the engine output, combustion efficiency, and emission decline in gases are AFR and mixture homogeneity which connect directly with the angle and position of the gas injector inside the intake manifold. Homogeneous mixing increased when combustion efficiency increases [14].

The main characteristics of gaseous fuel, which are regarded as a critical challenge facing gaseous fuel during mixture formation, are lower density and poorer fuel permeation. Although gaseous fuel can be rapidly blended with air due to its high diffusivity properties, it could be an inadequate period for blending, especially at a higher rotational speed of the engine. If the injector of gas is positioned at a wide area from the engine cylinder to permit more blending period, the inductive fuel may not enter inside the engine during the required duration. Furthermore, placing the injector near the combustion chamber affected the fluid to not blend correctly because of the short blending period. Hence, Enhancing the burning process and reducing environmental emissions is also closely linked to enhancing the uniformity of the blend (air-fuel) within the engine [15-18].

The orientation of the gas injector also impacts fluid blending properties, such as spread and turbulence. If the injector of gas is positioned in the opposite orientation to the flow of the air, the propagation and turbulence can be enhanced. But it relies on the momentum of the injection of gas fuel. If the gaseous fuel is pumped in the opposite path of the airflow with low pressure, it will not achieve the desired outcomes $[19,20]$. Although many reports on the blending properties of air with gaseous fuel have been published, the knowledge is limited for bi-engine worked with producer gas as fuel. Thus, in the presented research, a study has been created to investigate the effect of the gas injector position and direction on the uniformity and spread of the blend inside the intake manifold (air and producer gas) under a bi-engine using CFD software. This research will contribute to enhancing the economy of fuel, improving engine performance, and reducing emissions by determining the optimal location and angle orientation of the producer gas injector inside the intake manifold, which results in homogenous mixing for the producer gas and air mixture based on engine speed.

\section{Materials and methods}

2. 1. Improvement of the producer gas Injector position and angle within the Inlet Manifold

To obtain uniformity blend for the air with producer gas within the intake manifold under single-point injection, nine separate cases were generated to determine the effects of the injector positions and angles on the uniformity and propagation of the blend inside the intake manifold (Tables 1, 2 and Fig. 1). In this research, a manifold in the shape of an inverted «L», was utilized to enhance the orientation of the gas injector (position and angle). At three test points (P1, $\mathrm{P} 2$, and P3) with three different injection angles for each test point. A real test engine was used to model the dimensions of the intake manifold. 
Table 1

Air and producer gas properties $[8,17]$

\begin{tabular}{ccc}
\hline Properties & Air & Producer Gas \\
\hline Density $\left(\mathrm{Kg} / \mathrm{m}^{3}\right)$ & 1.225 & 0.9071756 \\
Viscosity $(\mathrm{Pa} \mathrm{s})$ & $1.179 \mathrm{E}-05$ & $1.49 \mathrm{E}-05$ \\
Specific Heat $(\mathrm{J} / \mathrm{kg} \mathrm{K})$ & 1005.148 & 3630.11 \\
Thermal Conductivity $(\mathrm{W} / \mathrm{m} \mathrm{K})$ & 0.0240 & 0.051785
\end{tabular}

Table 2

Supplied Producer Gas composition [1]

\begin{tabular}{cc}
\hline Component & Concentration \\
\hline Hydrogen & $19.16 \%$ \\
Carbon monoxide & $29.60 \%$ \\
Methane & $5.27 \%$ \\
Carbon dioxide & $5.41 \%$ \\
Nitrogen & $40.56 \%$
\end{tabular}

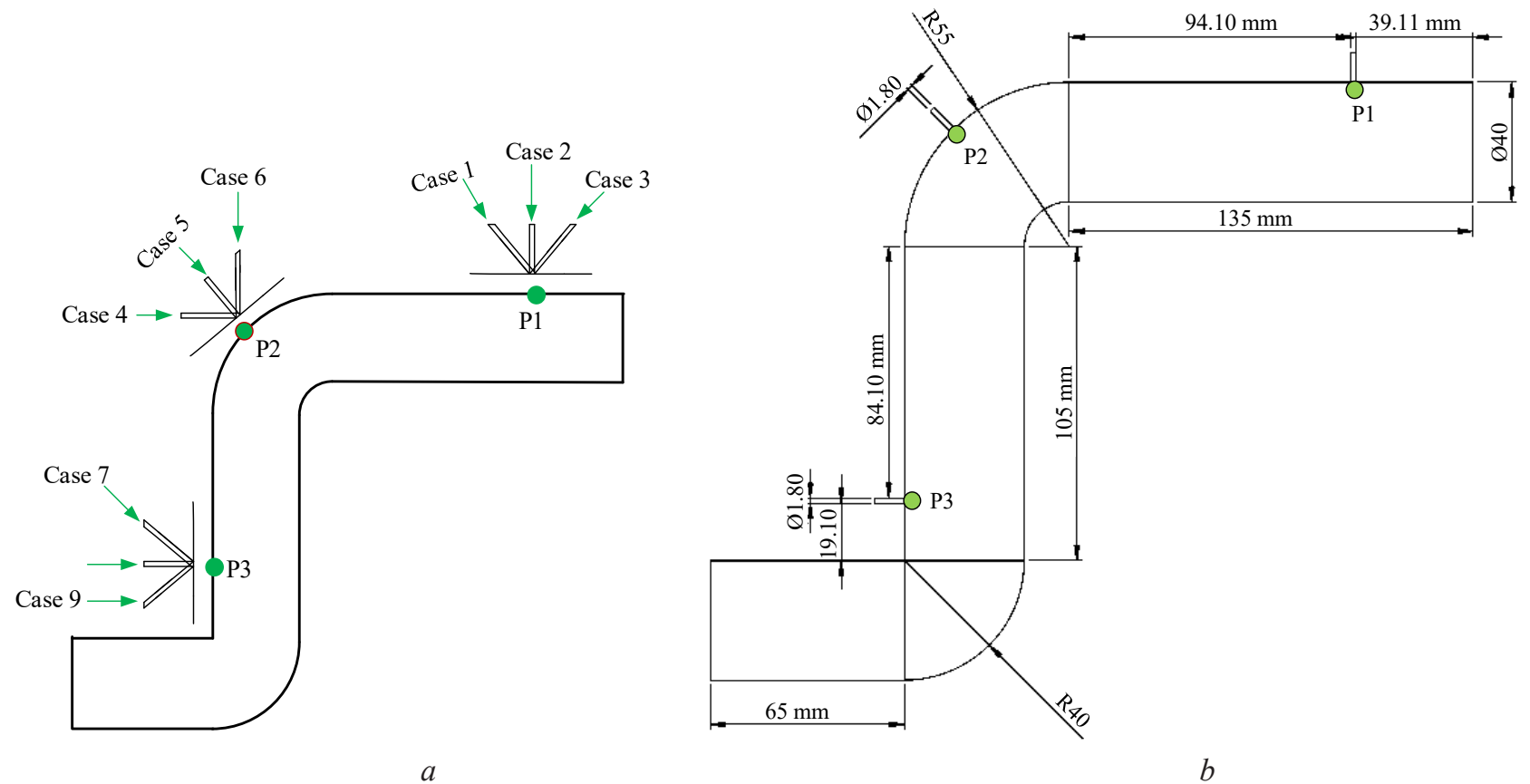

Fig. 1. Main parameters of inlet manifold with Producer Gas injector under different cases: $a$ - schematic view under different cases of injectors; $b$ - the main dimensions for manifold

Fig. 1 demonstrates the dimension of the intake manifold. The ANSYS workbench 19 program was employed to draw nine separate cases of single-point injection within the intake manifold. The specification of producer gas and air that used in this study, as shown in Table 1.

\section{2. CFD Analysis}

Intake manifold under single-point injection was modelled with ANSYS workbench CFD utilization, as shown in Fig. 2. Numerical simulation software (ANSYS fluent), was employed to simulate single-phase multi-species flow.

The equations of Reynolds Averaged Navier Stokes (RANS) govern the ANSYS fluent software. The RANS equations are solved by utilizing the algorithm of fully implicit, a finitevolume and pressure-based [13, 18-22]. 

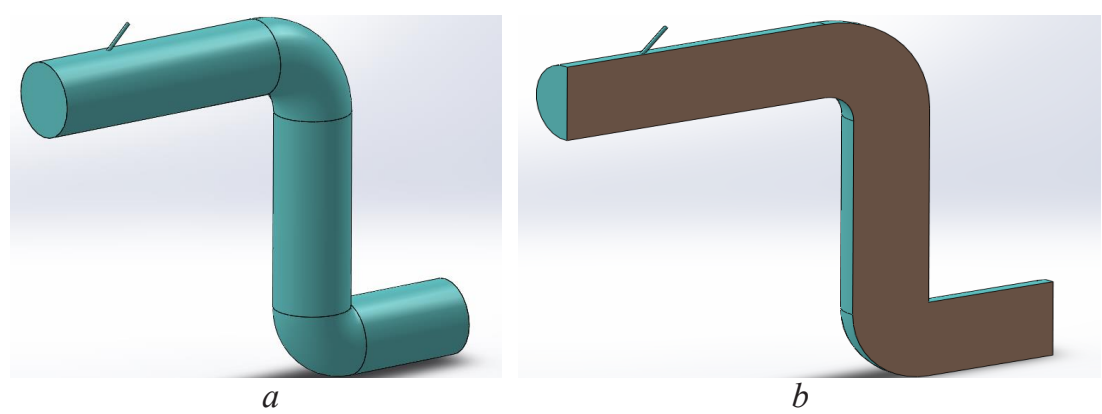

Fig. 2. Inlet manifold geometry after drawing with ANSYS workbench software: $a$ - Isometric display of the inlet manifold; $b$ - Inlet manifold section display

\section{2. 1. Grid Independent Test (GIT)}

ANSYS workbench 19 was used to mesh the nine separate cases of single-point injection within the inlet manifold. An Independent test (IT) was done on the intake manifold with the single producer gas injector (case 1$)$ at engine speed $(8000 \mathrm{rpm})$ and AFR $=2.07$. In order to conduct an independent test, six different models of meshing were selected (Table 3). ANSYS workbench program was employed to evaluate the grid-independent test on the geometry of the inlet manifold (model 1). The tetrahedron approach was used to mesh the six models, as seen in Fig. 3. Tetrahedral forms are applied in this approach to divide the inlet manifold geometry. For the six models, an independent test was carried out by comparing the findings of the producer gas mass fraction, and the UI at the inlet manifold outlet (model 1) as shown in Fig. 4, 5.

Table 3

Values of elements and nodes employed in IT under case 1

\begin{tabular}{ccc}
\hline Models & Elements & Nodes \\
\hline Model 1 & 211700 & 40570 \\
Model 2 & 350200 & 499065 \\
Model 3 & 495700 & 701200 \\
Model 4 & 668302 & 938789 \\
Model 5 & 795701 & 1114237 \\
Model 6 & 967719 & 1349342
\end{tabular}

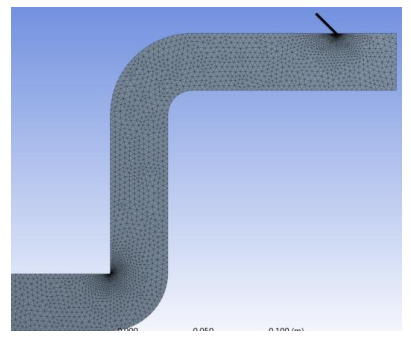

$a$

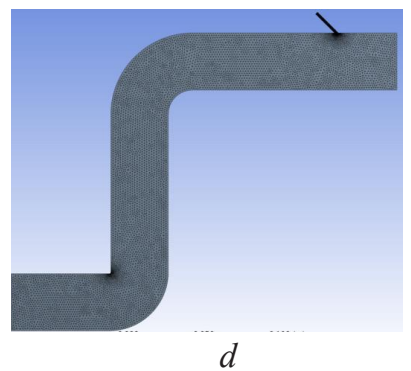

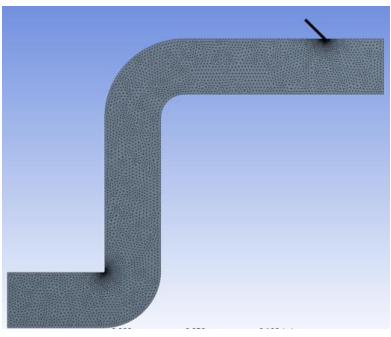

$b$

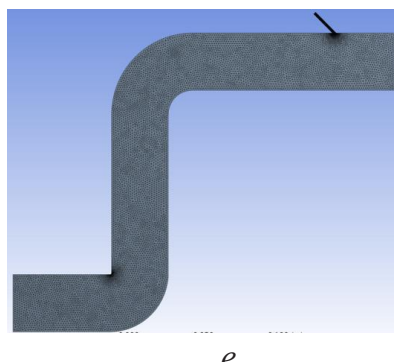

$e$
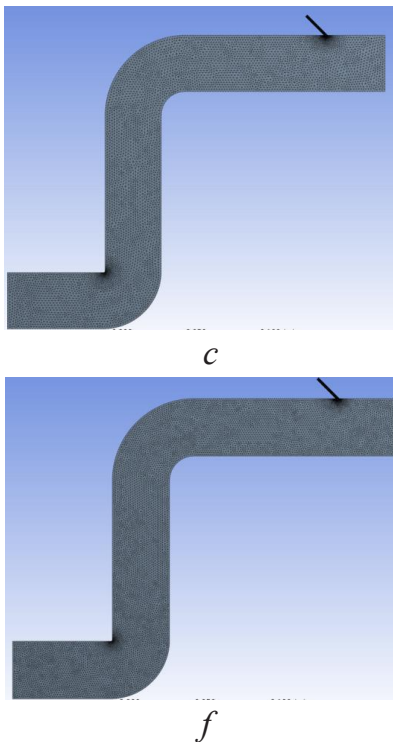

Fig. 3. Meshing models that are used in the IT under case 1: $a$-model $1 ; b$-model $2 ; c$ - model $3 ; d$-model $4 ; e$-model $5 ; f$-model 6 


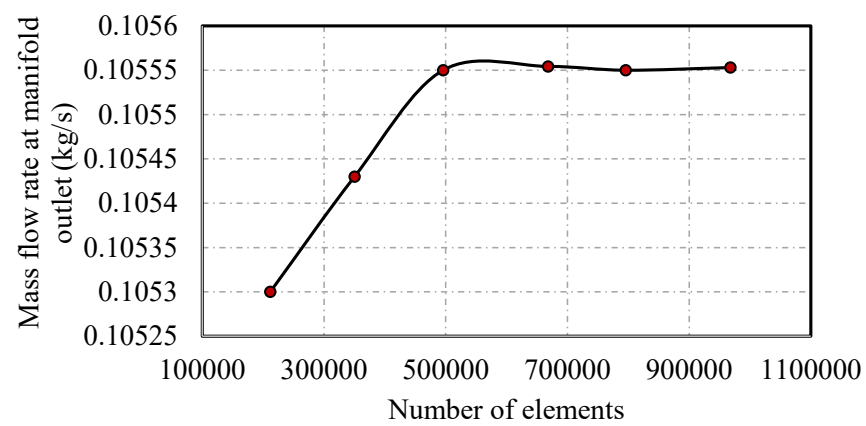

Fig. 4. The mass flow rate of the mixture at manifold outlet (case 1), IT results



Fig. 5. Uniformity index of the mixture at manifold outlet (case 1), IT results

Model 3 has been selected to apply to all cases based on IT, as it provides more precise outcomes and Saves the period of simulation.

\section{2. 2. Boundary Condition for the Inlet Manifold with producer gas Injector}

The mass flow rate was defined as initial conditions at the inlets and the outlet of the intake manifold under the nine different cases of single-point injection for producer gas inside manifold, as shown in Fig. 6.

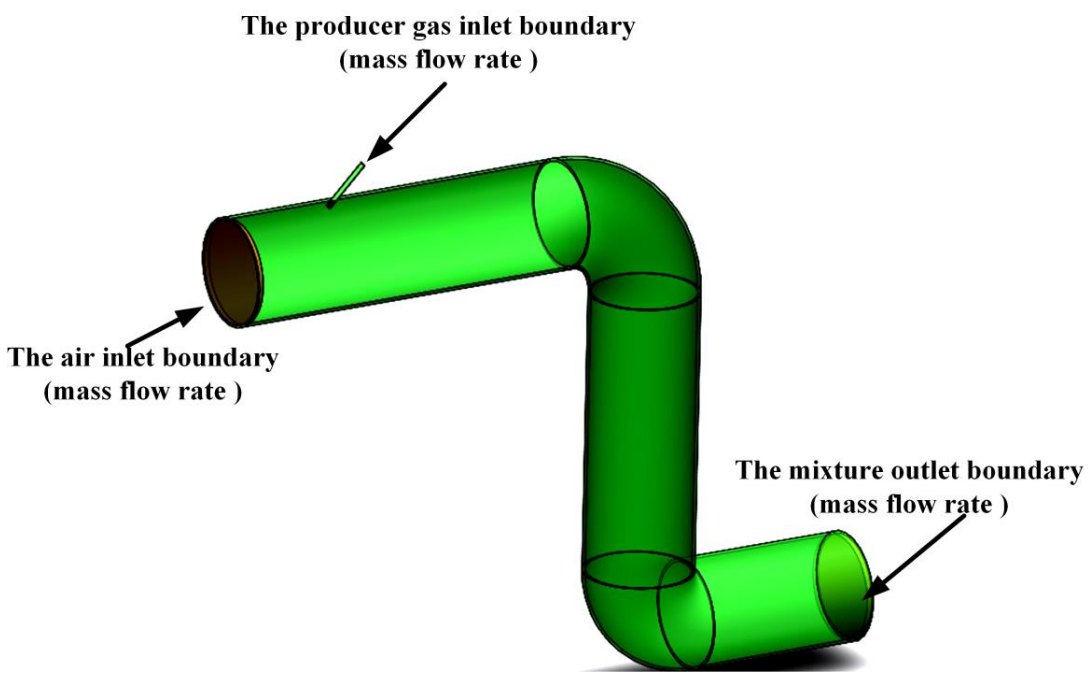

Fig. 6. The boundary conditions for the inlet manifold with producer gas injector

The air mass fraction through the air inlet is 1 while the producer gas mass fraction through producer gas inlet is $1[11,23]$. 


\section{Results and Discussion}

The calculation of producer gas mass fraction at the inlet of manifold and UI at the outlet of it are achieved by ANSYS software and mixture homogeneity is evaluated under AFR=2.07. UI indicator of mixture homogeneity is with ranges between 0 and 1 , when the UI value is equal to 1 ; the air is totally homogeneous with producer gas. Moreover, the producer gas is completely unmixed with air when the UI approaches zero. In addition, to achieve a uniform mixture of air and producer gas at the manifold outlet, producer gas concentration must be uniform and convergent. Fewer colour contours in the mixing area are denoted better blending for air and producing gas.

Single-point injection inside the manifold inlet was tested with nine different cases to figure out the UI values for producer gas at the manifold outlet, as indicated in Fig. 7. By the disparity, the highest UI values of 0.9999952 for producer gas are obtained using case 1, and the lowest value is 0.8636226 obtained from case 9 . Fig. 8, 9 demonstrate the contour and volume rendering of producer gas inside the nine different cases of single-point injection within the inlet manifold. Fig. 10 shows the mass fraction contour of producer gas at the manifold outlet of the nine different cases of single-point injection at the outlet of the inlet manifold under air-producer gas ratio 2.07. The analysis findings show that the highest concentration of producer gas is at the producer gas inlet. There is a significant variation in the spread of producer gas for the zones between the inlet of producer gas and the outlet of the manifold as shown in Fig. 8-10.

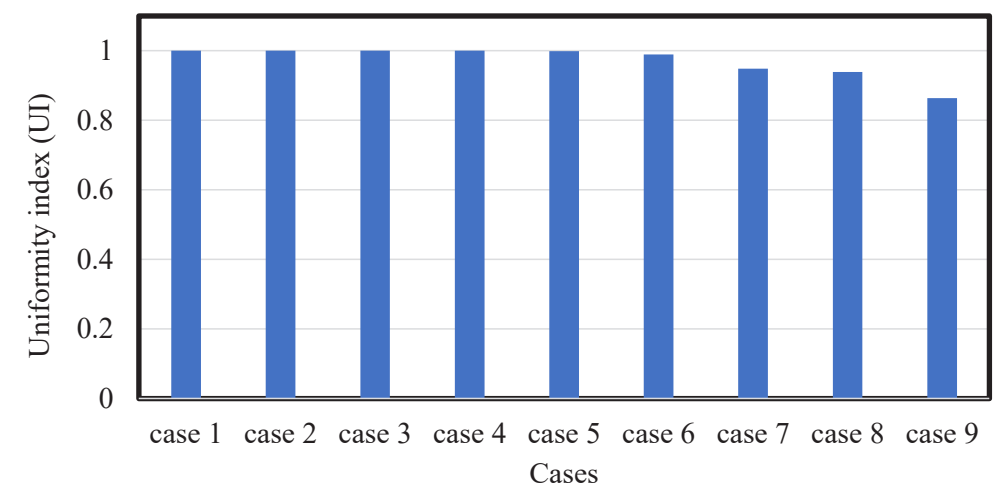

Fig. 7. Uniformity index values for producer gas according to the simulation findings for the nine different cases of single-point injection inside the inlet manifold
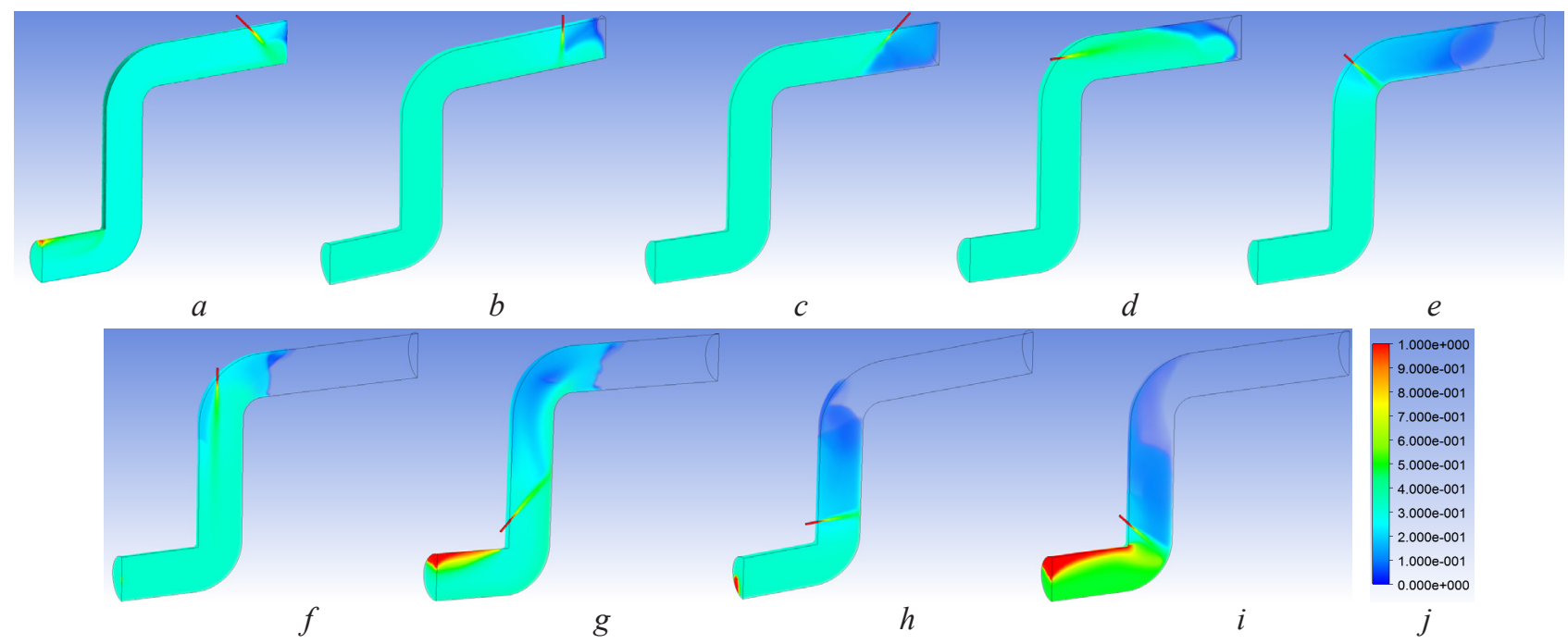

Fig. 8. Producer gas mass fraction volume rendering inside the nine different cases of single-point injection inside the inlet manifold under air- producer gas ratio 2.07:

$a$ - case $1 ; b$ - case $2 ; c$ - case $3 ; d$ - case $4 ; e$ - case $5 ; f$ - case $6 ; g$ - case 7 ; $h$ - case $8 ; i$ - case $9 ; j$ - scale 
As achieved from Fig. 8-10, the weakest spread of producer gas at the outlet of the manifold is observed in case 9 in comparison with the other cases. This outcome is due to the fact that the declining in the range between the producer gas injector and the manifold outlet decreases the blending period between the producer gas and air, consequently low mixture homogeneity.

Fig. 8-10 illustrate that all the cases that have producer gas injectors in the same path as the flow of air do not reach the sufficient blending (UI) for producer gas and air when the injector location is constant ( $\mathrm{P} 1$ or $\mathrm{P} 2$ or $\mathrm{P} 3)$. This outcome is attributable to the reality that the flow within the cases which include injector in the same path as the flow of air is similar to streamline flow inside the manifold with the low swirl. This status prevents the full mixing of producer gas with air.

Furthermore, the greatest uniformity and the maximum spread rate at the outlet of manifold when the producer gas injector location is constant (P1, P2, or P3) as shown in Fig. 1, are obtained in cases 1,4 , and 7 .

This finding is achieved because the orientation of the gas producer injector is opposite to the flow of air, that way permitting the production of intensely turbulence inflow and extreme swirls within the manifold and the blending of producer gas with air for as long as possible. Besides, case 1 indicates a better distribution of producer gas relative to the other cases (Fig. 7-10).

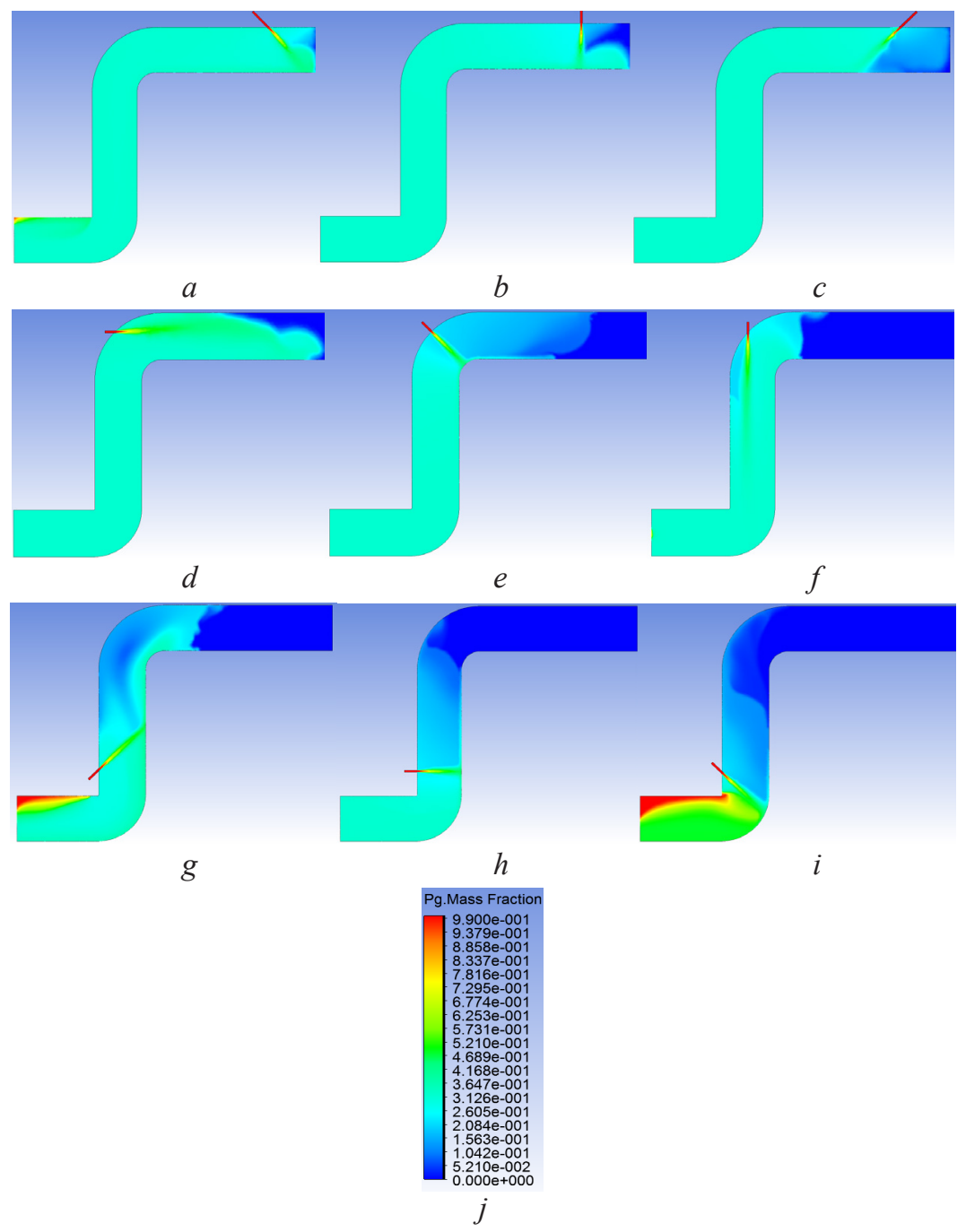

Fig. 9. Producer gas mass fraction contour at the plane inside the nine different cases of single-point injection inside inlet manifold under air- producer gas ratio 2.07:

$a$ - case $1 ; b$ - case $2 ; c$ - case $3 ; d$ - case $4 ; e$ - case $5 ; f$ - case $6 ; g$ - case 7 ;

$$
h \text {-case } 8 ; i \text {-case } 9 ; j \text { - scale }
$$




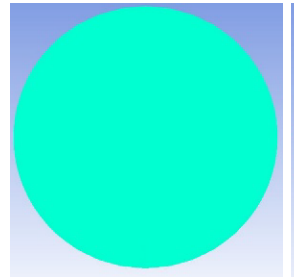

$a$

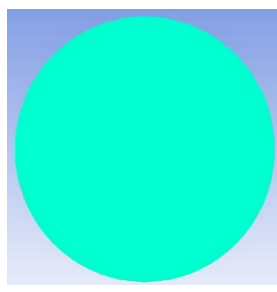

$d$

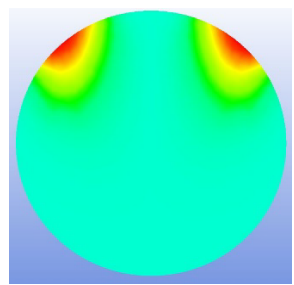

$g$

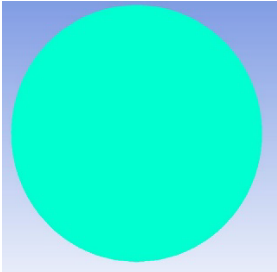

$b$

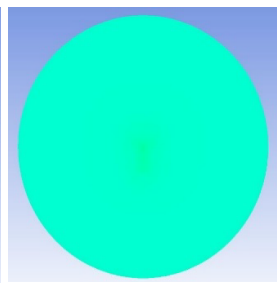

$e$

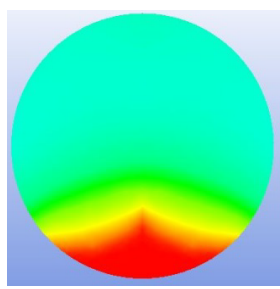

$h$

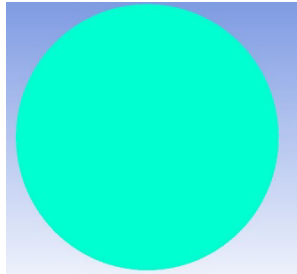

c

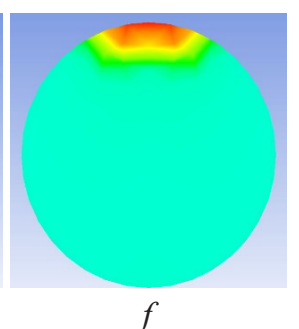

$f$

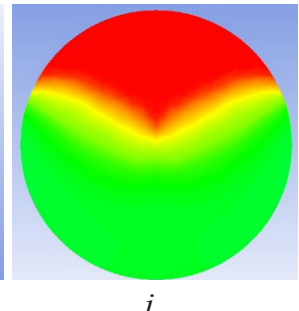

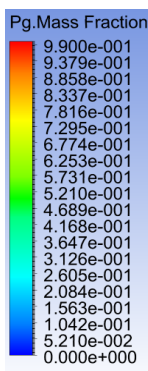

$j$

Fig. 10. Mass fraction contour of producer gas at the manifold outlet of the nine different cases of single-point injection at the outlet of the inlet manifold under air- producer gas ratio 2.07: $a$ - case $1 ; b$ - case $2 ; c$ - case $3 ; d$ - case $4 ; e$ - case $5 ; f$-case $6 ; g$ - case 7 ;

$$
h \text { - case } 8 ; i \text { - case } 9 ; j \text { - scale }
$$

\section{Discussion of numerical results}

This research contributes to improving the economy of fuel, improving the performance of the engine, and minimizing emissions by finding the best position and angle orientation of producer gas injector inside the intake manifold that leads to homogeneous mixing for producer gas and air mixture according to engine speed. In addition, the scope of this research is as follows:

1. ANSYS WORKBENCH 19 software was utilized to create nine separate models of the intake manifold with a single-point injector to investigate the effects of the injector positions and angles on the uniformity and propagation of the blend inside the intake manifold under AFR $=2.07$.

2. The nine separate models of the intake manifold with single-point injector were tested and checked with bi-engine mode (petrol-producer gas engine), $(1.6 \mathrm{~L})$ and the maximum engine speed $(8000 \mathrm{rpm})$.

While the limitation of this study can be summarized as follows.

This research did not deal with investigating and testing the performance of bi-engine experientially (petrol-producer gas) (power, emission, brake-specific fuel consumption (BSFC) and volumetric efficiency) with the new position and angle orientation of producer gas injector inside the intake manifold in state with and without supercharge. 


\section{Conclusion}

The nine different cases of single-point injection inside the inlet manifold were developed to evaluate the uniformity and propagation of the air-producing gas blend utilizing ANSYS Workbench 19. The outcomes of the simulation illustrate that several parameters, such as location and the injector orientation within the intake manifold influence the uniformity and homogeneity of the mixture for producer gas and air within the intake manifold. In addition, creating vortices and turbulent flow for the producer gas and air inside the intake manifold is the perfect method to obtain a uniformity mixture of air and producer gas inside the intake manifold. Furthermore, the producer gas must be in close contact with the air in order to be allowed to blend correctly. In addition, extending the blending duration allows air and producer gas fuel to be mixed efficiently. However, the length of the mixing period is essentially connected to the form of the flow. The outcomes of the analysis show that the highest UI values of 0.9999952 for producer gas are obtained using case 1 , and the lowest value is 0.8636226 obtained from case 9 .

\section{Acknowledgments}

We would like to extend our sincere gratitude to the support provided who given knowledge and insight that significantly helped the research.

\section{References}

[1] Alhamdany, A. A., Hameed, A. Q., Salman, Q. M. (2018). Experimental Investigation for the Removal of Toxic Gases from Vehicle Exhaust using Non-Thermal Plasma. Journal of Engineering, 24 (8), 55. doi: https://doi.org/10.31026/j.eng. 2018.08.05

[2] Ali, A. A. M. M., Ali, K., Kim, C., Lee, Y., Oh, S., Kim, K. (2019). Numerical Study of the Combustion Characteristics in a Syngas-diesel Dual-fuel Engine under Lean Condition. International Journal of Automotive Technology, 20 (5), $933-942$. doi: https://doi.org/10.1007/s12239-019-0087-7

[3] Pichayapat, K., Sukchai, S., Thongsan, S., Pongtornkulpanich, A. (2014). Emission characteristics of using HCNG in the internal combustion engine with minimum pilot diesel injection for greater fuel economy. International Journal of Hydrogen Energy, 39 (23), 12182-12186. doi: https://doi.org/10.1016/j.ijhydene.2014.06.004

[4] Karagöz, Y., Güler, İ., Sandalc1, T., Yüksek, L., Dalkılıç, A. S., Wongwises, S. (2016). Effects of hydrogen and methane addition on combustion characteristics, emissions, and performance of a CI engine. International Journal of Hydrogen Energy, 41 (2), 1313-1325. doi: https://doi.org/10.1016/j.ijhydene.2015.11.112

[5] Vinay, S., Ravi, S., Prema Kumar, G., Rajan, N. (2008). Numerical and experimental modeling of producer gas carburettor. Proc. of the International Conference on Advances in Mechanical Engineering.

[6] Suryawanshi, S., Yarasu, R. (2014). Design and Simulation of a Producer Gas Carburetor - A Review. International Journal of Current Engineering and Technology, 3, 10-13. Available at: http://inpressco.com/wp-content/uploads/2014/04/ Paper310-13.pdf

[7] Feng, S. (2017). Numerical Study of the Performance and Emission of a Diesel-Syngas Dual Fuel Engine. Mathematical Problems in Engineering, 2017, 1-12. doi: https://doi.org/10.1155/2017/6825079

[8] Dzombo, D., Kiplimo, R., Kiplagat, J. (2014). Use of Biomass Gas in Running Internal Combustion Engine to Generate Electricity-A Review. Proceedings of 2013 Mechanical Engineering Conference on Sustainable Research and Innovation, 5, 89-95. Available at: https://ir-library.ku.ac.ke/bitstream/handle/123456789/15469/Use\%20of\%20Biomass\%20Gas\%20in\%20 Running\%20Internal.pdf?isAllowed $=\mathrm{y} \&$ sequence $=1$

[9] Biradar, S., Ebinezar, R. R. (2013). Validation of Producer Gas Carburetor Using CFD. International Journal of Latest Research in Science and Technology, 2 (6), 90-94. Available at: https://www.mnkjournals.com/journal/ijlrst/pdf/ Volume_2_6_2013/10236.pdf

[10] Azimov, U., Okuno, M., Tsuboi, K., Kawahara, N., Tomita, E. (2011). Multidimensional CFD simulation of syngas combustion in a micro-pilot-ignited dual-fuel engine using a constructed chemical kinetics mechanism. International Journal of Hydrogen Energy, 36 (21), 13793-13807. doi: https://doi.org/10.1016/j.ijhydene.2011.07.140

[11] Mahmood, H. A., Adam, N. M., Sahari, B. B., Masuri, S. U. (2016). Investigation on the Air-Gas Characteristics of AirGas Mixer Designed for Bi-Engines. International Journal of Applied Engineering Research, 11 (12), 7786-7794. Available at: https://www.researchgate.net/profile/Hussein-Mahmood-4/publication/309072869_Investigation_on_the_air-gas_characteristics_of_air-gas_mixer_designed_for_bi-engines/links/5e7f8506299bf1a91b86624b/Investigation-on-the-air-gas-characteristics-of-air-gas-mixer-designed-for-bi-engines.pdf 
[12] Gorjibandpy, M., Sangsereki, M. K. (2010). Computational investigation of air-gas venturi mixer for powered bi-fuel diesel engine. World Academy of Science, Engineering and Technology, 4 (11), 1197-1201. Available at: https://publications. waset.org/1578/computational-investigation-of-air-gas-venturi-mixer-for-powered-bi-fuel-diesel-engine

[13] Danardono, D., Kim, K.-S., Lee, S.-Y., Lee, J.-H. (2011). Optimization the design of venturi gas mixer for syngas engine using three-dimensional CFD modeling. Journal of Mechanical Science and Technology, 25 (9), 2285-2296. doi: https:/doi.org/ 10.1007/s12206-011-0612-8

[14] Mahmood, H. A., Mariah Adam, N., Sahari, B. B., Masuri, S. U., Ahmed, H. E. (2019). An Investigation of Air-Gas Mixer Types Designed for Dual Fuel Engines: Review. Journal of Engineering and Applied Sciences, 14 (4), $1014-1033$. doi: https://doi.org/10.36478/jeasci.2019.1014.1033

[15] Mahmood, H. A., Mariah. Adam, N., Sahari, B. B., Masuri, S. U. (2018). Development of a particle swarm optimisation model for estimating the homogeneity of a mixture inside a newly designed CNG-H2-AIR mixer for a dual fuel engine: An experimental and theoretic study. Fuel, 217, 131-150. doi: https://doi.org/10.1016/j.fuel.2017.12.066

[16] Chintala, V., Subramanian, K. A. (2013). A CFD (computational fluid dynamics) study for optimization of gas injector orientation for performance improvement of a dual-fuel diesel engine. Energy, 57, 709-721. doi: https://doi.org/10.1016/ j.energy.2013.06.009

[17] Hagos, F. Y., Aziz, A. R. A., Sulaiman, S. A. (2014). Trends of Syngas as a Fuel in Internal Combustion Engines. Advances in Mechanical Engineering, 6, 401587. doi: https://doi.org/10.1155/2014/401587

[18] Yusaf, T., Yusoff, M. Z. (2000). Development of a 3D CFD model to investigate the effect of the mixing quality on the CNG-diesel engine performance. in Proceedings of the International Conference and Exhibition and Natural Gas Vehicles. Yokohama.

[19] Yusaf, T., Baker, P., Hamawand, I., Noor, M. M. (2013). Effect of Compressed Natural Gas Mixing on the Engine Performance and Emissions. International Journal of Automotive and Mechanical Engineering, 8, 1416-1429. doi: https://doi.org/10.15282/ ijame.8.2013.29.0117

[20] ANSYS FLUENT 12.0 Theory Guide. Available at: https://www.afs.enea.it/project/neptunius/docs/fluent/html/th/main_pre.htm

[21] Abo-Serie, E., Özgur, M., Altinsik, K. (2015). Computational analysis of methane-air venturi mixer for optimum design. Proceedings of the 13th International Combustion Symposium. Bursa, 9-11.

[22] Sharma, H., Singh, S., Goel, R. (2014). CFD analysis of the natural gas based Carburetor for a two stroke spark Ignition engine. National Conference on "Recent Advances in Mechanical Engineering" RAME - 2014. Available at: http://www.ijmerr.com/ SpecialIssue/12_(p.82-88).pdf

[23] Mahmood, H. A., Adam, N. M., Sahari, B. B., Masuri, S. U. (2016). Investigation On The Air-Gas Characteristics Of Air-Gas Mixer Designed For Dual Fuel-Engines. International Journal of Control Theory and Applications, 9 (30), 195-216.

How to cite: Mahmood, H. A., Al-Sulttani, A. O., Attia, O. H., Adam, N. M. (2021). A numerical study to improve the position and angle of the producer gas injector inside the intake manifold to minimize emissions and efficiency enhancement of a bi engine. EUREKA: Physics and Engineering, 5, 100-109. doi: https://doi.org/10.21303/2461-4262.2021.002045 